\title{
Intertidal and shallow water amphipods (Amphipoda: Gammaridea and Corophiidea) from Isla Pérez, Alacranes Reef, southern Gulf of Mexico
}

\author{
Carlos E. Paz-Ríos, Nuno Simões and Pedro-Luis Ardisson
}

(CEPR, PLA) Departamento de Recursos del Mar, Cinvestav, Carretera antigua a Progreso, km 6, Apdo. Postal 73, Cordemex 97310 Merida, Yucatan, Mexico. E-mails: (CEPR) cpaz@mda.cinvestav. mx (corresponding author); (PLA) ardisson@mda.cinvestav.mx

(NS) Universidad Nacional Autonoma de Mexico, Facultad de Ciencias, Unidad Multidisciplinaria de Docencia e Investigacion. Puerto de Abrigo s/n. Sisal, Yucatan, Mexico. E-mail: ns@ciencias.unam.mx

\begin{abstract}
Tropical coral reefs are known to exhibit high levels of biodiversity. Amphipod crustaceans are successfully adapted to a wide range of marine habitats in coral reefs, but some regions, such as the Campeche Bank in southern Gulf of Mexico, are poorly studied or even unsurveyed for amphipods. To begin to address this paucity of information, the present study records amphipod species from Isla Pérez, an island of the Alacranes Reef National Park, southern Gulf of Mexico. Twenty sites were sampled in the intertidal zone and shallow water adjacent to the island. Thirty-one species of amphipod were identified, 15 of which represented a geographical range extension to the northern Yucatan Peninsula, with four new records for the Mexican south-east sector of the Gulf of Mexico; nine for the Gulf Coast of Mexico; and two for the entire Gulf of Mexico. Significantly, a difference in faunal composition between windward and leeward areas of the intertidal zone was found.
\end{abstract}

Key words: Beach, biodiversity, coral reef, Peracarida, Yucatan

\section{INTRODUCTION}

Among the main types of coral reef (platform, barrier, fringing, and atoll), those that form islands (e.g. atoll) include an intertidal zone, an important habitat for species along the shoreline (Spalding et al., 2001). The intertidal zone of the coral reef islands (like that of the continent) is an area of transition between the sea and land, which represents an extreme habitat due to the periodic desiccation caused by tidal fluctuations (Knox, 2001).

Due to their high biodiversity, coral reefs have been compared to tropical rain forests (Connell, 1978). They display a great diversity of habitats, which are expected to harbor a correspondingly great diversity of species (Miloslavich et al., 2010). Much of this biodiversity is thought to consist of small, cryptic species of poorly characterized faunal groups, such as crustaceans (Plaisance et al., 2009; 2011). The cryptofaunal component of coral reefs is likely vastly underestimated, for instance, due to a high level of endemism such as that detected among the commensal leucothoid amphipods of sponges in southern Florida and the Caribbean (Richards et al., 2012).

In coral reef ecosystems, amphipods are one of the dominant macrobenthic crustaceans inhabiting virtually every available substratum(microhabitat) (Thomas, 1993), and the physically harsh environment of the intertidal zone has promoted an adaptive radiation in lifestyle and feeding mode 
(Bousfield, 1970). Nevertheless, because previous studies have focused heavily on the subtidal zone (McKinney, 1977; Winfield and Escobar-Briones, 2007; Lowry and Myers, 2009), amphipod diversity in the intertidal zone of the coral reef islands has not been adequately described.

Thus, although many intertidal amphipods have been reported in the Gulf of Mexico and Caribbean (Ortíz et al., 2007; LeCroy et al., 2009), with the exception of the relatively well-known amphipod fauna of the Florida Keys (Thomas, 1993), the amphipod species inhabiting the intertidal zone of the coral reef islands in the Gulf of Mexico are poorly documented. For the Gulf Coast of Mexico, studies of amphipods in coral reefs have mostly recorded families/species from the subtidal zone (McKinney, 1977; EscobarBriones and Winfield, 2003; Escobar-Briones and Jiménez-Guadarrama, 2010; Winfield et al., 2011). Notably, Escobar-Briones and Jiménez-Guadarrama (2010) suggested that the western Campeche Bank is a "hotspot" of biological diversity for the macrocrustaceans associated with the carbonated bottoms on the continental shelf, with the greatest number of families found in the proximity of the bank reefs and coral reef islands.

The present study aims to improve knowledge of the marine benthic fauna associated with the Alacranes Reef, and forms part of a long-term effort to explore the diversity of poorly characterized taxa in the region (e.g. crustaceans, sponges, echinoderms, opisthobranchs, and cryptic fish). Preliminary results from this research have already been published by Anker (2010; 2012), Anker and De Grave (2010), Moreno-Mendoza et al. (2011), and Paz-Ríos et al. (2013). Here, we describe the amphipod species (documenting the extension of their geographical range) of the intertidal zone and shallow waters from Isla Pérez, Alacranes Reef, southern Gulf of Mexico.

\section{Material and Methods}

Alacranes Reef is an atoll-like platform reef located approximately $130 \mathrm{~km}$ off northern Yucatan Peninsula in the Campeche Bank, SE Gulf of Mexico (Fig. 1A), forming part of the
North America's marine ecoregion 14 (Southern Gulf of Mexico) situated on the Campeche/ Yucatanean Outer Neritic region (Wilkinson et al., 2009). Alacranes Reef contains a large variety of relatively well-conserved habitats (Liceaga-Correa and Hernández-Núñez, 2000; Jordán-Dahlgren and Rodríguez-Martínez, 2003), and many coral patches and microatolls in the reef lagoon (Arias-González et al., 2012). The atoll-like platform has a semi-elliptic shape with an extension of approximately $26 \mathrm{~km}$ in length and a width of $15 \mathrm{~km}$ (Liceaga-Correa and Hernández-Núnez, 2000), including five sandy coral reef islands: Chica, Desterrada, Desertora or Muertos, Pájaros or Blanca and Pérez (Fig. 1B). Isla Pérez is the only inhabited island and the second largest island (just below the Isla Desterrada) according to the estimated data (area and perimeter) of Liceaga-Correa and Hernández-Núnez (2000). Isla Pérez is a low-lying sand cay that varies in outline as dictated by seasonal storms and wind directions (Kornicker et al., 1959; Folk and Robles, 1964). The tidal range in Isla Pérez is about $0.9 \mathrm{~m}$ (Folk and Robles, 1964), slightly greater than the range $(0.7 \mathrm{~m})$ for the coastal zone on northern Yucatan peninsula (CuevasJimenéz and Euán-Ávila, 2009). Folk and Robles (1964) and Folk (1967) presented the sedimentary description of Isla Pérez.

Twenty sites were arbitrarily selected on the intertidal zone and shallow water adjacent to Isla Pérez (Fig. 1C; Tab. 1); three of them $(8,14$ and 20) were sampled twice at different times. Collection of samples involved different sampling devices (core, hand, Riley push-net, shovel, and suction sampler) and no standardized area or volume of sampling was used. Several types of coastal habitats were probed, such as beaches of homogeneous white sand, coral rubble bars, sea grass beds of Thalassia testudinum (Banks ex König, 1805), sandy bottoms, and shallow coral reef flats. All samples were treated with $\mathrm{MgCl}_{2}$, and then fixed with $10 \%$ formalin solution buffered with seawater before storage. In the laboratory, samples were washed through a $500 \mu \mathrm{m}$ size mesh and transferred to $70 \%$ ethanol. Species were sorted and identified to the lowest possible taxonomical rank. Specimens are deposited 
and vouchered at the regional collection 'Crustáceos de Yucatán' (YUC-CC-255-11), UNAM-Sisal. Species classification follows LeCroy et al. (2009) and species composition is presented in the form of a checklist of species; only those species with a geographical range extension were annotated. Geographical range is represented by three nested spatial scales: i) Mexican south-east sector of the Gulf of Mexico, ii) Gulf Coast of Mexico, and iii) Gulf of Mexico.

The species distribution around Isla Pérez was explored at those stations of the intertidal zone located to the East on the windward side (stations 1, 6-15) and to the West on the leeward side (stations 2-5) of the island (Fig. 1C). A non-metric multidimensional scaling ordination analysis (MDS) was applied to a species matrix of presence/absence with the Sorensen coefficient as similarity index due to the differences in sampling effort and sampling devices at the different stations. To test the significance of species distribution explored in the MDS, an analysis of similarities (ANOSIM) was applied and an analysis of similarity percentages (SIMPER) with a cut off for low contributions of $75 \%$ was carried out to identify the main species on each side of the island. The statistical software used for analyses was PRIMER v6 (Clarke and Gorley, 2006).
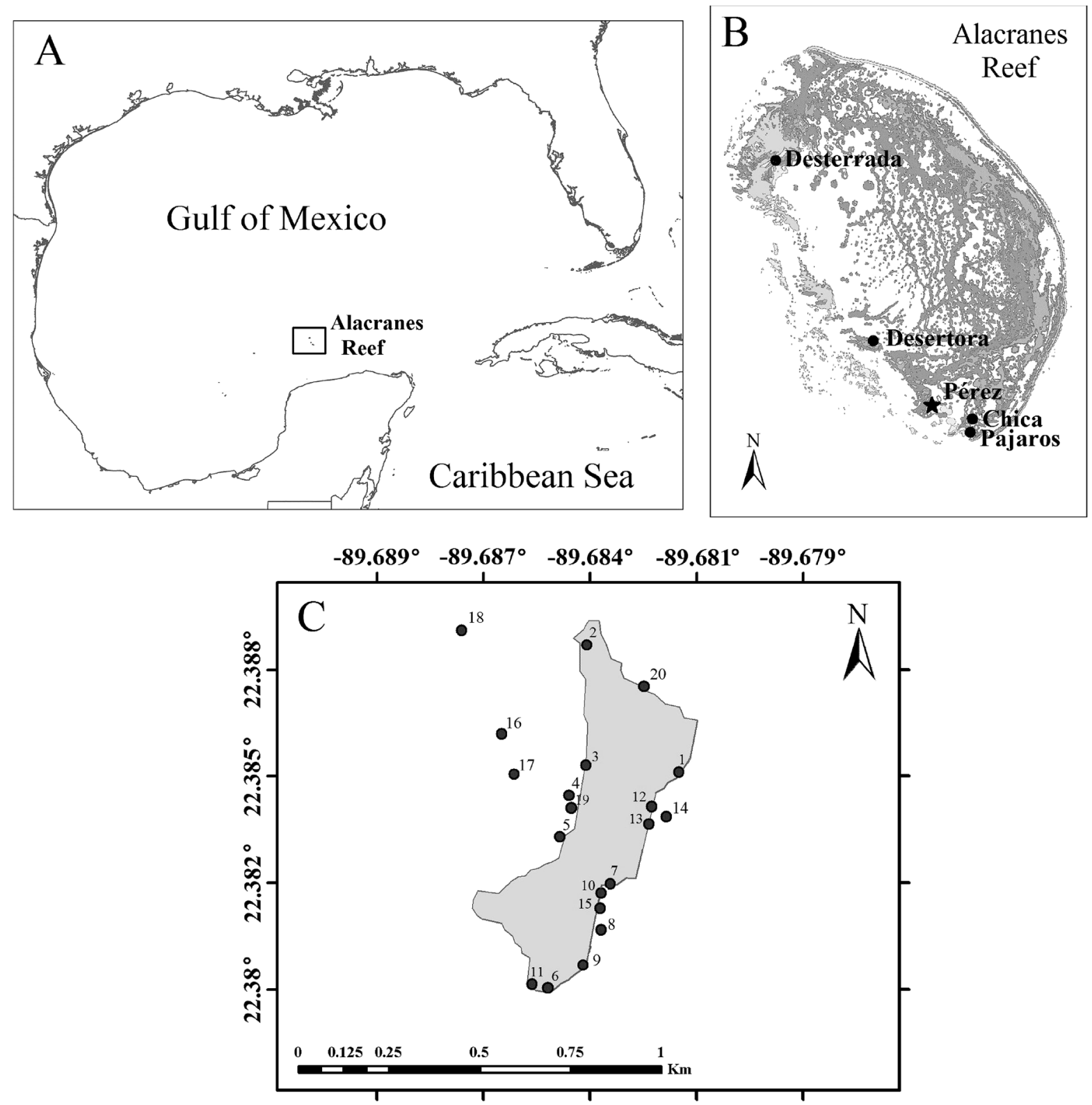

Figure 1. Location maps of the study area. (A) Alacranes Reef, southern Gulf of Mexico. (B) Coral reef islands in Alacranes Reef. (C) Sampling sites on Isla Pérez. 
Table 1. Sampled sites summary. Site: (4') duplicate sampling site at the space, (8”, 14", 20") duplicate sampling sites at the time. Sampling device: (Co) Core, (Ha) Hand, (Pn) Riley push-net, (Sh) Shovel, (Su) Suction sampler. Zone: (I) Intertidal, (Sw) Shallow water.

\begin{tabular}{|c|c|c|c|c|c|c|}
\hline Site & Latitude $(\mathrm{N})$ & Longitude (W) & Date & Sampling device & Zone & Habitat \\
\hline 1 & $22^{\circ} 23^{\prime} 01.2^{\prime \prime}$ & $89^{\circ} 40^{\prime} 55.2^{\prime \prime}$ & $08 / 11 / 09$ & Sh & I & Sandy beach \\
\hline 2 & $22^{\circ} 23^{\prime} 13.9^{\prime \prime}$ & $89^{\circ} 41^{\prime} 00.7^{\prime \prime}$ & 08/11/09 & Sh & I & Sandy beach \\
\hline 3 & $22^{\circ} 23^{\prime} 03.2^{\prime \prime}$ & $89^{\circ} 41^{\prime} 00.8^{\prime \prime}$ & 08/11/09 & Sh & I & Sandy beach \\
\hline 4 & $22^{\circ} 23^{\prime} 00.5^{\prime \prime}$ & $89^{\circ} 41^{\prime} 02.3^{\prime \prime}$ & 08/04/09 & Co & I & Sandy beach \\
\hline 4 & $22^{\circ} 23^{\prime} 00.5^{\prime \prime}$ & $89^{\circ} 41^{\prime} 02.3^{\prime \prime}$ & 08/04/09 & $\mathrm{Ha}$ & Sw & Shallow coral reef flat with sponge \\
\hline 5 & $22^{\circ} 22^{\prime} 56.8^{\prime \prime}$ & $89^{\circ} 41^{\prime} 03.1^{\prime \prime}$ & 08/13/09 & Sh & I & Sandy beach with shell debris \\
\hline 6 & $22^{\circ} 22^{\prime} 45^{\prime \prime}$ & $89^{\circ} 41^{\prime} 05^{\prime \prime}$ & 08/07/09 & $\mathrm{Ha}$ & I & Coral rubble \\
\hline 7 & $22^{\circ} 22^{\prime} 53.5^{\prime \prime}$ & $89^{\circ} 40^{\prime} 59.2^{\prime \prime}$ & 08/13/09 & $\mathrm{Ha}$ & I & Coral rubble \\
\hline 8 & $22^{\circ} 22^{\prime} 51.2^{\prime \prime}$ & $89^{\circ} 40^{\prime} 59.8^{\prime \prime}$ & 08/06/09 & $\mathrm{Ha}$ & I & Coral rubble \\
\hline $8 "$ & $22^{\circ} 22^{\prime} 51.2^{\prime \prime}$ & $89^{\circ} 40^{\prime} 59.8 ”$ & 08/09/09 & $\mathrm{Ha}$ & I & Coral rubble covered by Thalassia wrack \\
\hline 9 & $22^{\circ} 22^{\prime} 47.4^{\prime \prime}$ & $89^{\circ} 41^{\prime} 00.7^{\prime \prime}$ & 08/09/09 & $\mathrm{Ha}$ & I & Coral rubble covered by Thalassia wrack \\
\hline 10 & $22^{\circ} 22^{\prime} 53.3$ & $89^{\circ} 40^{\prime} 59.9^{\prime \prime}$ & 08/11/09 & $\mathrm{Ha}$ & I & Coral rubble covered by Thalassia wrack \\
\hline 11 & $22^{\circ} 22^{\prime} 45.3^{\prime \prime}$ & $89^{\circ} 41^{\prime} 06.4^{\prime \prime}$ & 08/13/09 & $\mathrm{Ha}$ & I & Coral rubble covered by Thalassia wrack \\
\hline 12 & $22^{\circ} 22^{\prime} 57.3^{\prime \prime}$ & $89^{\circ} 40^{\prime} 57.3^{\prime \prime}$ & 08/01/09 & Pn & I & Thalassia bed \\
\hline 13 & $22^{\circ} 22^{\prime} 56.3^{\prime \prime}$ & $89^{\circ} 40^{\prime} 57.8^{\prime \prime}$ & 08/02/09 & Pn & I & Thalassia bed \\
\hline 14 & $22^{\circ} 22^{\prime} 56^{\prime \prime}$ & $89^{\circ} 40^{\prime} 56.4^{\prime \prime}$ & 08/09/09 & $\mathrm{Ha}$ & I & Thalassia bed \\
\hline $14 "$ & $22^{\circ} 22^{\prime} 56^{\prime \prime}$ & $89^{\circ} 40^{\prime} 56.4^{\prime \prime}$ & 08/13/09 & $\mathrm{Su}$ & I & Thalassia bed \\
\hline 15 & $22^{\circ} 22^{\prime} 52.7^{\prime \prime}$ & $89^{\circ} 41^{\prime} 00.0^{\prime \prime}$ & 08/13/09 & $\mathrm{Ha}$ & I & Thalassia bed \\
\hline 16 & $22^{\circ} 23^{\prime} 06^{\prime \prime}$ & $89^{\circ} 41^{\prime} 08.3^{\prime \prime}$ & 08/14/09 & $\mathrm{Su}$ & Sw & Sandy bottom \\
\hline 17 & $22^{\circ} 23^{\prime} 02.4^{\prime \prime}$ & $89^{\circ} 41^{\prime} 07.2^{\prime \prime}$ & 08/14/09 & $\mathrm{Su}$ & Sw & Sandy bottom \\
\hline 18 & $22^{\circ} 23^{\prime} 18.9^{\prime \prime}$ & $89^{\circ} 41 ' 13.9^{\prime \prime}$ & 08/05/09 & $\mathrm{Ha}$ & Sw & On Strombus shell \\
\hline 19 & $22^{\circ} 22^{\prime} 59.4^{\prime \prime}$ & $89^{\circ} 41^{\prime} 02.1 ”$ & 08/08/09 & $\mathrm{Ha}$ & Sw & On Strombus shell \\
\hline 20 & $22^{\circ} 23^{\prime} 10.2^{\prime \prime}$ & $89^{\circ} 40^{\prime} 55.6^{\prime \prime}$ & 08/01/09 & Co & Sw & Thalassia bed; Shallow coral reef flat \\
\hline $20 "$ & $22^{\circ} 23^{\prime} 10.2^{\prime \prime}$ & $89^{\circ} 40^{\prime} 55.6^{\prime \prime}$ & 08/11/09 & Sh & $\mathrm{I}$ & Sandy beach with shell debris \\
\hline
\end{tabular}

\section{RESUlTS}

A total of 1217 specimens were collected, belonging to 31 species, 26 genera, 17 families and two suborders (Tab. 2). The families Aoridae, Leucothoidae and Melitidae showed the greatest richness, accounting $47 \%$ of the dominance of amphipods. The most abundant species were Colomastix sp., Cymadusa filosa Savigny, 1816, Eudevenopus honduranus Thomas and Barnard, 1983, Melita planaterga Kunkel, 1910, Metharpinia floridana (Shoemaker, 1933), Parhyale hawaiensis (Dana, 1853), and Tethorchestia antillensis Bousfield, 1984, which together accounted for about $90 \%$ of the amphipods collected in the intertidal zone and shallow water. Fifteen species defined a geographical range extension to the northern Yucatan Peninsula (Tab. 2). Four of them are new records for the Mexican south-east sector of the Gulf of Mexico, nine for the Gulf Coast of Mexico and two for the Gulf of Mexico; these species are annotated below.

\section{Taxonomy}

Order Amphipoda Latreille, 1816

Suborder Gammaridea Latreille, 1802

Family Dexaminidae Leach, 1814

Nototropis minikoi (Walker, 1905) (Fig. 2A)

Distribution: Northwestern Atlantic; Gulf of Mexico; Caribbean; Indo-Pacific (LeCroy, 2004; Ortíz et al., 2007; LeCroy et al., 2009).

Records in the Gulf of Mexico: Cedar Key; Carrabelle; St. Andrew Bay (Shoemaker, 1932); Terminos Lagoon (Ledoyer, 1986); Soto la Marina; Camaronera Lagoon (Cházaro-Olvera et al., 2002); Mexican Laguna Madre (Barba and Sánchez, 2005); Northwestern Cuba (Ortiz and Lalana, 2010). 
Table 2. Checklist of amphipod crustaceans in Isla Pérez, Alacranes Reef. (•) Species with a geographical range extension. The voucher refers to the reference number(s) in the collection. Site: (4’) duplicate sampling site at the space, (8”, 14”, 20”) duplicate sampling sites at the time.'

\begin{tabular}{|c|c|c|c|c|c|}
\hline Suborder & Family & Species & Site & Abundance & Voucher \\
\hline \multirow{25}{*}{ 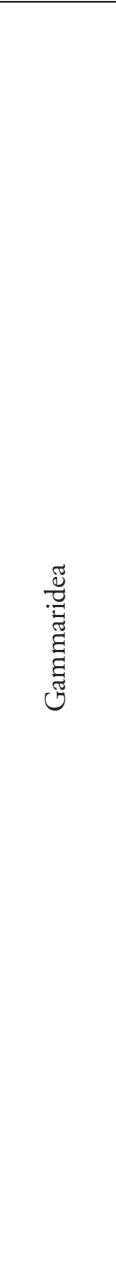 } & Ampeliscidae & Ampelisca brevisimulata Barnard, 1954 & 16 & 2 & 1 \\
\hline & Amphilochidae & Apolochus sp. & 20 & 1 & 6 \\
\hline & Bateidae & Batea cuspidata (Shoemaker, 1926) & $4,5,20$ & 5 & $9-11$ \\
\hline & Colomastigidae & Colomastix sp. & 4 & 67 & 12 \\
\hline & Dexaminidae & - Nototropis minikoi (Walker, 1905) & $1,2,7,14,20$ & 9 & $13-17$ \\
\hline & Hyalidae & Parhyale hawaiensis (Dana, 1853) & $1,5,8,8^{\prime}, 14,20^{\prime}$ & 202 & $19-24$ \\
\hline & \multirow[t]{4}{*}{ Leucothoidae } & Anamixis cavatura Thomas, 1997 & $4^{\prime}, 20$ & 4 & 28,29 \\
\hline & & - Leucothoe laurensi Thomas and Ortíz, 1995 & 18 & 1 & 30 \\
\hline & & - Leucothoe ubouhu Thomas and Klebba, 2007 & 18 & 4 & 31 \\
\hline & & Leucothoe sp. & 4', 5,20 & 15 & $35-37$ \\
\hline & Lysianassidae & Lysianopsis alba Holmes, 1903 & $2,3,5,14$ & 19 & $38-41$ \\
\hline & Megaluropidae & Gibberosus myersi (McKinney, 1980) & 16,17 & 3 & 42,43 \\
\hline & \multirow[t]{6}{*}{ Melitidae } & - Anamaera hixoni Thomas and Barnard, 1985 & 20 & 6 & 44 \\
\hline & & Ceradocus shoemakeri Fox, 1973 & 14 & 2 & 45 \\
\hline & & -Elasmopus thomasi Ortíz and Lalana, 1994 & 18 & 8 & 49 \\
\hline & & -Elasmopus sp. B sensu LeCroy, 2000 & $1,18,20$ & 20 & $50-52$ \\
\hline & & - Maeracoota galani Krapp-Schickel and Ruffo, 2001 & 18 & 3 & 53 \\
\hline & & - Melita planaterga Kunkel, 1910 & $2,3,5,7,14^{\prime}, 20$ & 219 & $54-59$ \\
\hline & \multirow[t]{2}{*}{ Oedicerotidae } & Americhelidium americanum (Boudfield, 1973) & 16 & 1 & 64 \\
\hline & & Hartmanodes nyei (Shoemaker, 1933) & 16,17 & 3 & 65,66 \\
\hline & Phliantidae & -Pariphinotus seclusus (Shoemaker, 1933) & 18 & 2 & 67 \\
\hline & \multirow[t]{2}{*}{ Phoxocephalidae } & •Eobrolgus spinosus (Holmes, 1905) & 18,20 & 2 & 68,69 \\
\hline & & Metharpinia floridana (Shoemaker, 1933) & $4,14,16,17$ & 39 & $70-73$ \\
\hline & Platyischnopidae & Eudevenopus honduranus Thomas and Barnard, 1983 & $2,5,16,17$ & 27 & $74-77$ \\
\hline & Talitridae & - Tethorchestia antillensis Bousfield, 1984 & $6,8,9,10,11$ & 146 & $86-90$ \\
\hline \multirow{6}{*}{ 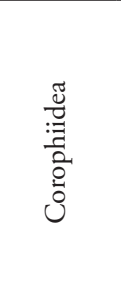 } & \multirow[t]{4}{*}{ Aoridae } & - Bemlos spinicarpus (Pearse, 1912) & 18,20 & 3 & 91,92 \\
\hline & & - Bemlos unicornis (Bynum and Fox, 1977) & 19 & 2 & 93 \\
\hline & & Bemlos sp. & 1,20 & 2 & 94,95 \\
\hline & & -Lembos unifasciatus reductus Myers, 1979 & $14^{\prime}, 20$ & 3 & 96,97 \\
\hline & \multirow[t]{2}{*}{ Ampithoidae } & Cymadusa filosa Savigny, 1816 & $1,4^{\prime}, 8,12,13,14,14^{\prime}, 15$ & 396 & $109-116$ \\
\hline & & - Pseudamphithoides incurvaria (Just, 1977) & 18 & 1 & 117 \\
\hline
\end{tabular}

Habitat: Sandy bottoms, algae, sea grass beds, plankton; depth range from 1 to $3 \mathrm{~m}$ (LeCroy, 2004; Ortíz et al., 2007).

Remarks: This is the first record for the Mexican south-east sector of the Gulf of Mexico. The main identifying characteristics of this species are antenna 1 shorter than antenna 2; articles 3-4 of antenna 2 peduncle with dorsal clumps of setae; mandible with welldeveloped palp; pleon without dorsal process; coxal gills 2-5 dendritic; urosome carinate with segments 2-3 fused; telson deeply cleft with terminal spine on lobes. This species is very similar to Nototropis urocarinatus (McKinney, 1980), another species of the genus in the Gulf of Mexico; these species are highly related such that a synonymization has been proposed in LeCroy et al. (2009).

Family Leucothoidae Dana, 1852 Leucothoe laurensi Thomas and Ortíz, 1995 (Fig. 2B)

Distribution: Gulf of Mexico; Caribbean; Brazil (White, 2011a; b).

Records in the Gulf of Mexico: Looe Key Reef (Thomas and Ortíz, 1995). 
Habitat. Fine sand, coral rubble; depth range from 0 to $50 \mathrm{~m}$ (Thomas and Ortíz, 1995; White, 2011a; b).

Remarks: This is the first record for the Gulf Coast of Mexico. The main characteristics that distinguish this species from other species in the genus Leucothoe are dactyl of gnathopod 1 long (reaching beyond tip of carpal lobe); propodus of gnathopod 2 with nearly transverse palm; propodus of gnathopod 2 with long, blade-like anterodistal process.

Leucothoe ubouhu Thomas and Klebba, 2007 (Fig. 2C)

Distribution: Gulf of Mexico; Caribbean (White, 2011a).

Records in the Gulf of Mexico: Loggerhead Key (Thomas and Klebba, 2007).

Habitat. Coral rubble, commensal on sponges; depth range from 1 to $15 \mathrm{~m}$ (Thomas and Klebba, 2007; White, 2011a; b).

Remarks: This is the first record for the Gulf Coast of Mexico. The main identifying characteristics of this species are the extremely long dactyl of gnathopod 1; anteroventral margin of head with slight concavity; propodus of gnathopod 2 with palm linear and two or three strong tubercles; females are distinct among Western Atlantic species in having a tuft of numerous long posterodistal setae on basis of gnathopod 1 .

Family Melitidae Bousfield, 1973 Anamaera hixoni Thomas and Barnard, 1985 (Fig. 2D)

Distribution: Southeastern Florida; Gulf of Mexico (Thomas and Barnard, 1985).

Records in the Gulf of Mexico: Looe Key Reef; Lee Country; Hillsborough Country (Thomas and Barnard, 1985; Krapp-Schickel and Vader, 2009).

Habitat: Alga-covered and spongecovered rubble, usually over a sand bottom; depth range from 1 to $37 \mathrm{~m}$ (Thomas and Barnard, 1985; LeCroy, 2000; Krapp-Schickel and Vader, 2009).
Remarks: This is the first record for the Gulf Coast of Mexico. The main characteristics identifying this species are inner plate of maxilliped with slender process on each side of distal margin; antenna 1 with accessory flagellum four-articulated; body setose dorsally; gnathopod 2 of male, right and left sides dissimilar, one side much larger than other; uropod 3, rami subequal in length; telson with strong dorsolateral spines at midpoint of each lobe.

Elasmopus thomasi Ortíz and Lalana, 1994

(Fig. 2E)

Distribution: Gulf of Mexico; Caribbean (Ortíz and Lalana, 1994; 1996; Varela et al., 2003; Ortíz et al., 2007; LeCroy et al., 2009).

Records in the Gulf of Mexico: Miramar (Ortíz and Lalana, 1994).

Habitat: Among beds of detritus-covered algae; depth range from $<1$ to $3 \mathrm{~m}$ (Ortíz and Lalana, 1994; LeCroy et al., 2009).

Remarks: This is the first record for the Gulf Coast of Mexico. The main identifying characteristics of this species are antenna 2 with a small flagellum; propodus with dorsal and ventral margins almost parallel, palm with three tubercles; epimeron 3 having three ventrolateral tufts of robust setae.

Elasmopus sp. B sensu LeCroy, 2000

(Fig. 2F)

Distribution: Gulf of Mexico (LeCroy, 2000).

Records in the Gulf of Mexico: Long Key (LeCroy, 2000).

Habitat. Among algae on rubble or sand bottoms; depth range from 1 to $2 \mathrm{~m}$ (LeCroy, 2000).

Remarks: This is the first record for the Gulf Coast of Mexico. Based on LeCroy (2000), this species is different to other known Gulf of Mexico species of Elasmopus by virtue of a posteroventral margin with very small tooth or cusp on coxa 1, an enlarged carpus with a sharply angled dorsal margin and a broad carpal lobe on gnathopod 2 and a concave, distally narrowing basis on peraeopod 5 . 
Maeracoota galani Krapp-Schickel and Ruffo, 2001 (Fig. 2G)

Distribution: Caribbean (Krapp-Schickel and Ruffo, 2001; Ortíz et al., 2007).

Records in the Gulf of Mexico: Previously unreported.

Habitat: Among algae (Goniolithon sp.); depth range from 0.5 to $3 \mathrm{~m}$ (Krapp-Schickel and Ruffo, 2001).

Remarks: This is the first record for the Gulf of Mexico. So far the genus Maeracoota contains two geographically distant species: M. galani (western Atlantic) and Maeracoota tridentate Myers, 1997 (Indopacific). They are very similar, but the former species is distinguished by a tooth on urosomite 2 (absent in $M$. tridentata), observable also in juveniles, males or females (Krapp-Schickel and Ruffo, 2001).

\section{Melita planaterga Kunkel, 1910}

(Fig. 2H)

Distribution: Bermuda; Gulf of Mexico (Lazo-Wasem and Gable, 1987; LeCroy et al., 2009; Gable et al., 2010).

Records in the Gulf of Mexico: Florida Keys; Ten Thousand Islands; Terminos lagoon (Ledoyer, 1986; LeCroy, 2000).

Habitat: Shallow rubble or rock habitats with abundant algal growth, sea grass beds of Thalassia sp. and sometimes in night plankton tows over sea grass beds and rubble bottoms; depth range from the intertidal to $5 \mathrm{~m}$ (LazoWasem and Gable, 1987; LeCroy, 2000; LeCroy et al., 2009). Melita planaterga has recently been recorded in a continental water body called Cenote Aerolito on Cozumel Island by Trujillo-Pisanty et al. (2010). Cenotes commonly occur in the Yucatan peninsula; they are classified as anchialine since they are characterized by a salinity gradient due to the connection with the sea (Mejía-Ortíz et al., 2006).

Remarks: This is the first record for the Mexican south-east sector of the Gulf of Mexico. Even though there were already records from the Gulf of Mexico, Gable et al. (2010) listed this species for Bermuda as endemic. The main identifying characteristics of this species are palm of gnathopod 2 entire or oblique with inner facial surface adjacent to palm forming depression; pleon dorsally smooth; epimeron 3 produced behind to form large tooth; urosome segment 1 with short medial mucronation on posterior margin, and urosome segment 2 with lateroposterior spine.

Family Phliantidae Stebbing, 1899

Pariphinotus seclusus (Shoemaker, 1933)

(Fig. 2I)

Distribution: Southeastern United States; Gulf of Mexico; Caribbean; Brazil (Lazo-Wasem et al., 1989; Ortíz et al., 2007; LeCroy et al., 2009; LeCroy, 2011).

Records in the Gulf of Mexico: Apalachee Bay; Florida Bay; Florida Keys; Port Isabel (Shoemaker, 1933; McKinney, 1977; Lewis, 1987; Thomas, 1993).

Habitat: Coral rubble with benthic foraminiferans, as an epibiont of the queen conch, in algae, coral rubble, limestone pieces on sandy bottoms, Thalassia sp. beds, silty or muddy sand, and among soft corals; depth range from the intertidal to $59 \mathrm{~m}$ (LazoWasem et al., 1989; Lewis, 1987; Thomas, 1993; Oliva-Rivera, 2003; LeCroy, 2011).

Remarks: This is the first record for the Gulf Coast of Mexico. The main identifying characteristics of this species are anterior margin of rostrum weakly concave; peraeon segment 1 with narrow central notch on dorsal carina; basis of peraeopods 5-6 with posterior lobe reduced.

Family Phoxocephalidae Sars, 1895

Eobrolgus spinosus (Holmes, 1905)

(Fig. 2J)

Distribution: Eastern United States; Gulf of Mexico; Caribbean; Northeastern Pacific (Bousfield, 1973; Barnard and Barnard, 1981; Ortíz et al., 2007; LeCroy et al., 2009).

Records in the Gulf of Mexico: Florida Bay; Florida Keys; Charlotte Harbor; Tampa Bay to Apalachee Bay; Terminos lagoon; Bay of 
Campeche; Tamiahua lagoon (Ledoyer, 1986;

Escobar-Briones and Winfield, 2003; Winfield et al., 2006; LeCroy, 2011).

Habitat: Sandy bottoms in bays, estuaries and open beaches, from sea grass beds of Thalassia sp. (presumably in sand patches), among plankton, and associated with polychaete worm reefs; depth range from 0.5 to $1290 \mathrm{~m}$ (Bousfield, 1973; Charvat et al., 1990; Martín and Díaz, 2003; Winfield et al., 2006; LeCroy, 2011).

Remarks: This is the first record for the Mexican south-east sector of the Gulf of Mexico. The main characteristics for identifying this species are rostrum entire and broad at base; eye well-developed; carpus of gnathopods 1-2 elongate, distinctly longer than merus; merus and carpus of peraeopods 5-6 slender to slightly expanded, moderately spinose; and dactyl of peraeopods 5-7 short.

Family Talitridae Bulycheva, 1957

Tethorchestia antillensis Bousfield, 1984

(Fig. 2K)

Distribution: Gulf of Mexico; Caribbean (Ciavatti, 1989; Bousfield, 1984; Oliva-Rivera, 2003; LeCroy et al., 2009).

Records in the Gulf of Mexico: Florida Keys to Marco Island (LeCroy, 2011).

Habitat: Under the leaf litter of mangrove and sea grass beds; depth range from the supratidal/intertidal to $0.5 \mathrm{~m}$ (Oliva-Rivera, 2003; LeCroy et al., 2009; LeCroy, 2011).

Remarks: This is the first record for the Gulf Coast of Mexico. The main characteristics for identifying this species are antenna 2, peduncle slender, subequal to or shorter than flagellum; gnathopods 1-2 subchelate; propodus of peraeopod 7 with setal tufts on the distomedial margin; peduncle of uropod 1 with well-developed dorsolateral distal spine, outer ramus of uropod 1 without marginal spines; and ramus of uropod 3 cylindrical, tapering distally and tip subacute.

Suborder Corophiidea Leach, 1814 Infraorder Corophiida Leach, 1814

Superfamily Aoroidea Stebbing, 1899 Family Aoridae Walker, 1908
Bemlos spinicarpus (Pearse, 1912)

(Fig. 2L)

Distribution: Southeastern Florida; Bahamas; Gulf of Mexico; Caribbean (Myers, 1979; Thomas, 1993; Oliva-Rivera, 2003; LeCroy et al., 2009; Ortíz and Lalana, 2010).

Records in the Gulf of Mexico: Florida Keys (Pearse, 1912; Myers, 1979).

Habitat. Among algae or sea grass beds, on muddy, sandy or shelly bottoms, as an epibiont of the queen conch; depth range from 1 to $8 \mathrm{~m}$ (Pearse, 1912; LeCroy, 2002, OlivaRivera, 2003).

Remarks: This is the first record for the Gulf Coast of Mexico. This species was identified here with female specimens; therefore, no subspecies of $B$. spinicarpus (Bemlos spinicarpus inermis [Myers, 1979] or Bemlos spinicarpus spinicarpus [Pearse, 1912]) could be determined because these subspecies are indistinguishable in females (LeCroy, 2002). The main characteristics for identifying females of this species are body with pigmentation; ocular lobe rounded; coxae 1-4 contiguous, wider than deep; propodus of gnathopod 1 subequal to carpus in length, with palmar margin flat, convex and without defining tooth; basis of peraeopods 5-7 slender; distoventral process on peduncle of uropod 1 long; inner ramus of uropod 3 longer than peduncle.

Bemlos unicornis (Bynum and Fox, 1977)

(Fig. 2M)

Distribution: Southeastern United States; Bermuda; Bahamas; Gulf of Mexico; Caribbean; Brazil (Myers, 1977; Thomas, 1993; Ortíz et al., 2007; LeCroy et al., 2009).

Records in the Gulf of Mexico: Tarpon Springs; Central West Florida shelf; Florida Keys; Terminos lagoon (Myers, 1981; Ledoyer, 1986; LeCroy, 2002).

Habitat. Among algae, sea grass beds or sponges, on muddy or shelly bottoms, in fouling growth on hard substrata, and sometimes in night plankton tows; depth range from 0.3 to $18 \mathrm{~m}$ (Bynum and Fox, 1977; Myers, 1977; 1981; LeCroy, 2002). 


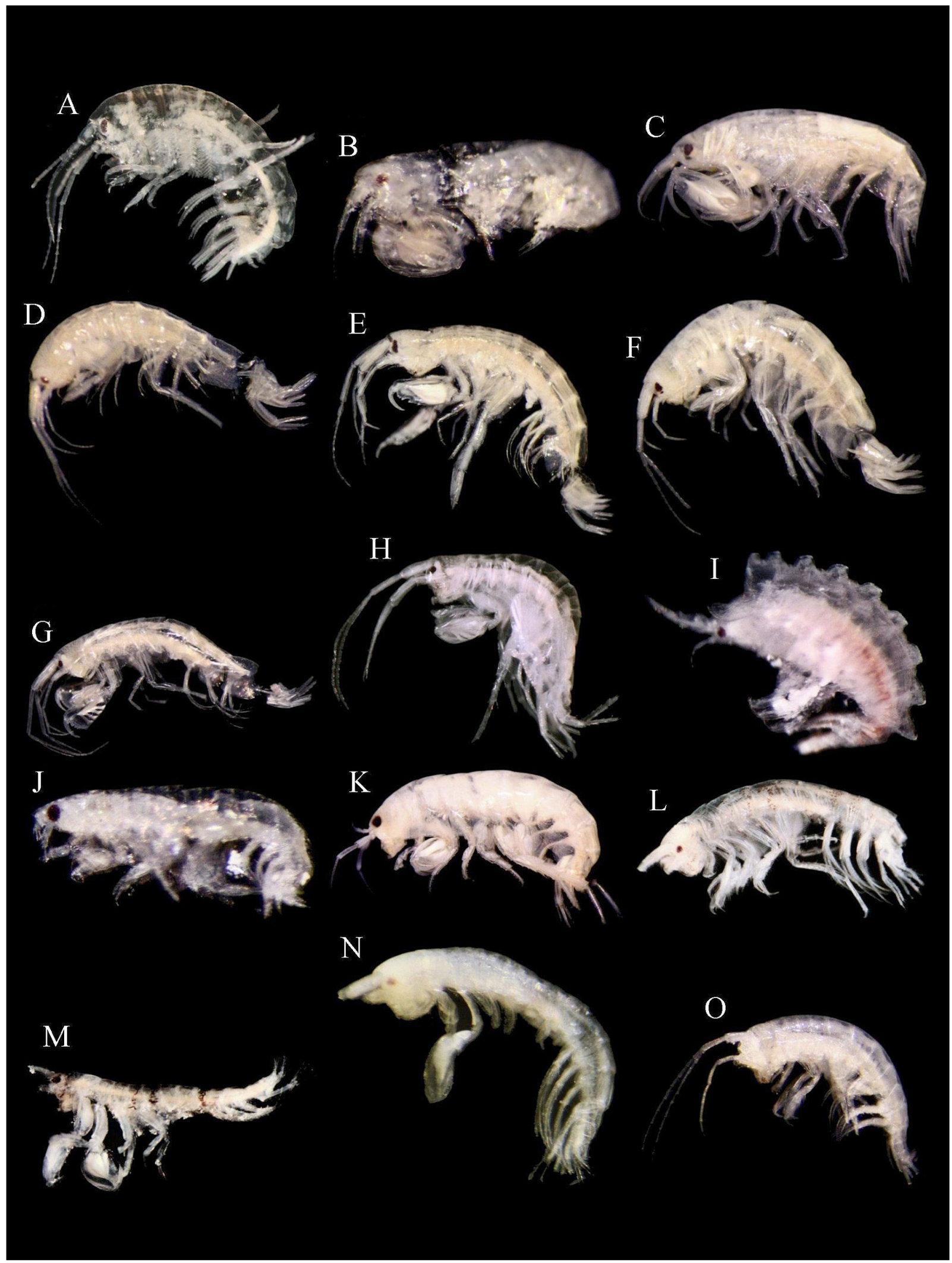

Figure 2. Amphipod crustaceans (males, except where is indicated) collected in Alacranes Reef with a geographical range extension. (A) Nototropis minikoi (Walker, 1905). (B) Leucothoe laurensi Thomas and Ortíz, 1995. (C) Leucothoe ubouhu Thomas and Klebba, 2007. (D) Anamaera hixoni Thomas and Barnard, 1985, female. (E) Elasmopus thomasi Ortíz and Lalana, 1994. (F) Elasmopus sp. B sensu LeCroy, 2000. (G) Maeracoota galani Krapp-Schickel and Ruffo, 2001. (H) Melita planaterga Kunkel, 1910. (I) Pariphinotus seclusus (Shoemaker, 1933). (J) Eobrolgus spinosus (Holmes, 1905). (K) Tethorchestia antillensis Bousfield, 1984. (L) Bemlos spinicarpus (Pearse, 1912), female. (M) Bemlos unicornis (Bynum and Fox, 1977). (N) Lembos unifasciatus reductus Myers, 1979. (O) Pseudamphithoides incurvaria (Just, 1977) 
Remarks: This is the first record for the Mexican south-east sector of the Gulf of Mexico. The main identifying characteristics of this species are head with dorsal pigment; anteromedial surface of propodus on gnathopod 1 sparsely setose; anterior margin of carpus and propodus on gnathopod 2 with long, dense setae; anterior margin of basis on gnathopod 1-2 without long marginal and submarginal setae; anterior margin of basis on gnathopod 1 crenulate; and palm of propodus on gnathopod 1 with shallow notch.

\section{Lembos unifasciatus reductus Myers, 1979}

(Fig. 2N)

Distribution: Southeastern Florida; Gulf of Mexico; Caribbean (LeCroy, 2002; Ortíz et al., 2007; LeCroy et al., 2009).

Records in the Gulf of Mexico: Apalachee Bay; Central West Florida shelf; Cape Romano to lower Florida Keys (Myers, 1979; LeCroy, 2002).

Habitat. In sandy or shelly bottoms; depth range from 2 to 73 m (Myers, 1979; LeCroy, 2002).

Remarks: This is the first record for the Gulf Coast of Mexico. This subspecies, along with subspecies Lembos unifasciatus unifasciatus Myers, 1977, actually belongs in the genus Bemlos, pending its formal transfer to that genus (Myers, A.A. personal communication in LeCroy, 2002). The short distoventral process of $L$. unifasciatus reductus on the peduncles of uropods 1 and 2 distinguishes this species from those of other Bemlos (Myers, 1981; LeCroy, 2002).

Superfamily Corophioidea Leach, 1814

Family Ampithoidae Boeck, 1871

Pseudamphithoides incurvaria (Just, 1977)

(Fig. 2O)

Distribution: Bahamas; Caribbean (Just, 1977; Lewis and Kensley, 1982).

Records in the Gulf of Mexico: Previously unreported.

Habitat: Among hydroids and algae (Dictyota bartayresii Lamouroux, 1809,
Dictyota ciliolata Kützing, 1859 and Dyctiopteris sp.), with a remarkable domiciliary biology; domiciles (regular tubes or irregular "caves") are normally composed of a glandular secretion usually covered with finer sediment or detritus and algal fragments (Just, 1977; Lewis and Kensley, 1982). This species has been collected in the low tide zone and shallow water (1.5 to $27 \mathrm{~m}$ depths) on $D$. bartayresii (Just, 1977; Lewis and Kensley, 1982).

Remarks: This is the first record for the Gulf of Mexico. So far the genus Pseudamphithoides contains only two species in the tropical western Atlantic reported by Ortíz et al. (2007): Pseudamphithoides bacescui Ortiz, 1976 and P. incurvaria. The latter species is mainly distinguished from $P$. bacescui by the narrower inner plate of maxilla 1 , more robust setae (9) on the outer plate of maxilla 1 (5 on P. bacescui) and setose posterior margin of basis on peraeopod 4 (Karaman and Barnard, 1979). Pseudamphithoides incurvaria from Alacranes Reef corresponds well to the description of the material from Barbados by Just (1977); the only difference is the presence of two robust setae on apex of inner ramus on uropod 3 (without robust setae in P. incurvaria from Barbados).

\section{Species distribution on Isla Pérez}

The MDS ordination analysis divided sampling stations into roughly two groups representing the faunal composition of the intertidal zone on the East (windward) side and West (leeward) side of Isla Pérez, respectively (Fig. 3). Although the sampling methods employed varied and the sampling areas have different environmental and oceanographic characteristics, this result suggests broad similarity of faunal composition across each of the two regions identified, i.e. the windward and leeward sides of the island. The contribution (explained variance) to the ordination by the windward sites was $55 \%$, whereas the contribution to the ordination by the leeward sites was $45 \%$. The ANOSIM test reinforced this statement, detecting a significant difference $(\mathrm{R}=0.321, \mathrm{p}=0.006)$ between the faunal composition of both side 
of the island. The SIMPER analysis identified the main species distinguishing each side of the island, giving abundance and relative contribution (Ind, \%): on the windward side, Melita planaterga (52 Ind, 94\%) was the major species, while on the leeward side the major species were Cymadusa filosa (34 Ind, 27\%) and Tethorchestia antillensis (13 Ind, 64\%).

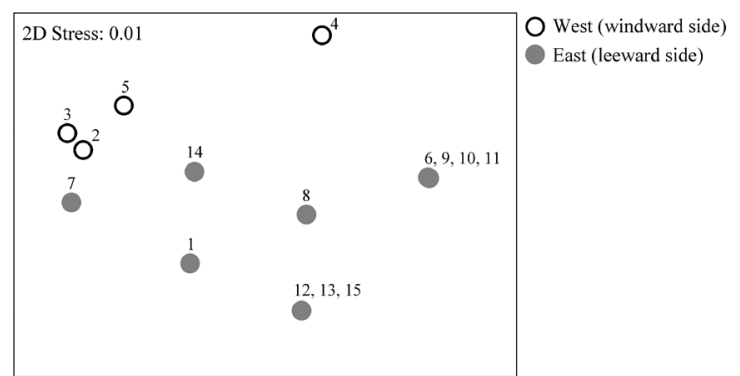

Figure 3. Non-metric multidimensional scaling ordination analysis (MDS) among stations $(\mathrm{n}=15)$ on the intertidal zone in Isla Pérez. Overlap of two groups of sampling stations due to a high similarity on the fauna identity.

\section{Discussion}

Distribution of amphipod species on Isla Pérez

The spatial species distribution around Isla Pérez matches the distribution of specific island habitats, and relates to the lifestyle of each species. The geomorphology of the Alacranes Reef is highly complex, with direct implications for species distribution. In particular, Isla Pérez forms part of the reef crest barrier on the eastern windward side, where the island resists, absorbs and dissipates wave energy, while on the leeward side there is an extensive area of flow and ebb to the interior lagoon (CONANP, 2006). Each geomorphological condition is associated with a characteristic amphipod species composition.

On the West (leeward) side of Isla Pérez, where the shoreline is protected and composed of sandy beaches, the most frequent and abundant species of amphipod in the intertidal zone was Melita planaterga; this species has previously been found in the intertidal zone on rock habitats with abundant algal growth (Lazo-Wasem and Gable, 1987; LeCroy, 2000). Although the SIMPER analysis did not identify Lysianopsis alba as a main species, it was the second most frequent and abundant species on the island's leeward side. In coastal areas this species is usually found on muddy or silty sand or shell hash bottoms, along protected or semiprotected shores (LeCroy, 2007).

On the other hand, on the East (windward) side of the island, where the shoreline is exposed and composed of sandy beaches with sea grass beds and rubble beaches with corals and broken shells, the species Cymadusa filosa was highly abundant on sea grass beds of Thalassia testudinum. In sea grass beds and among algae, $C$. filosa has been reported with high abundance, tube-building behavior and detritivory habit (Zimmerman et al., 1979; Appadoo and Myers, 2003). Other species, such as Parhyale hawaiensis (another species not identified by the SIMPER analysis) and Tethorchestia antillensis, were found in large numbers in rubble intertidal beaches. The former species usually inhabits the region from the intertidal zone to shallow water, among algae and other fouling growth on hard substrata (e.g. piers, jetties, oyster beds, mangroves, and coral rubbles) (LeCroy, 2007), whereas the latter species often inhabits the supratidal zone, under the leaf litter of mangrove (LeCroy, 2011); in the intertidal zone of Isla Pérez, it is found under the leaves of $T$. testudinum on rubble beaches along the shoreline. For highly mobile supratidal fringe species, such as talitrid amphipods (including T. antillensis), with a high tolerance of aerial conditions, mangrove leaves and sea grass beds potentially provide both food and shelter (Porri et al., 2011; terHorst, 2012).

Those species with low abundance in the intertidal zone, but greater abundance in the shallow water adjacent to Isla Pérez, were Eudevenopus honduranus and Metharpinia floridana. Both species were collected on sand bottoms from the shallow water on the West (leeward side) of the island, and are typical examples of the most widespread infaunal families (Platyischnopidae and Phoxocephalidae, respectively) in sandy sediments of tropical coastal areas (Bousfield, 1970; Thomas, 1993). 
Amphipods of the Alacranes Reef

With 256 species, the amphipod fauna of the Great Barrier Reef, Australia, is the richest fauna yet known from any tropical reef area (Lowry and Myers, 2009). In contrast, amphipods on Gulf of Mexico coral reefs have not been the subject of detailed systematic study (Thomas, 1993; Baldinger, 2000). Nevertheless, there are independent summaries for two southern coral reef areas: Thomas (1993) for the Florida Key Reefs and Winfield et al. (2011) for the Veracruz Reef System. The first of these pointed out that the number of species identified at that time (52 spp.) represented approximately one-third of the total number of species in the Florida Key reefs; the second study reported an accumulated number of 63 amphipod species on the Veracruz Reef System. In the Alacranes Reef, there are 44 recorded species from 22 families, of which 31 are reported in the present study, with the 13 remaining species being recorded in a study of fouling species in the Reef's navigation buoys (Paz-Ríos et al., 2013).

Comparing the faunal composition of the Alacranes Reef with other coral reefs in the Mexican Atlantic, it is apparent that the Alacranes Reef shares more species with coral reefs of the Mexican Caribbean than with coral reefs of the southwestern Gulf of Mexico. As expected, the Alacranes Reef shares an intermediate number of amphipod families (14 of 28 families, $50 \%$ similarity) with those identified in the coral reefs in the western sector of the Campeche Bank by EscobarBriones and Jiménez-Guadarrama (2010). At the same taxonomic rank, the Alacranes Reef shares few amphipod families (11 of 27 families, $41 \%$ similarity) with those identified in the Veracruz Reef System by Winfield and Ortiz (2011); at the species rank, the Alacranes Reef shares a relatively low number of species (two of 68 spp., 3\% similarity) with the Veracruz Reef System. It is also instructive to compare the Alacranes Reef with the Mexican Caribbean reef Banco Chinchorro, although this has been poorly sampled spatially, only recording 25 species of gammarideans sensu lato for the entire coral reef (Oliva-Rivera, 2003). Notwithstanding this qualification, using the same principles of comparison, there are relatively few amphipod families (11 of 27 families, $41 \%$ similarity) shared between the Alacranes Reef and the Banco Chinchorro; this was also reflected at the species rank, where the Alacranes Reef shares only a small number of species (six of 64 spp., 9\% similarity) with those identified in the Banco Chinchorro.

In the above cases, despite the differences in habitats studied and sampling methods, a comparison of the faunal composition among coral reefs in the Mexican Atlantic could be useful as baseline for developing biogeographic studies, for instance, to assess endemism using presence/absence data or to identify discrete ecoregions.

Based on the species listed in this study, there is a remarkable number of new records for northern Yucatan Peninsula (15 spp.), accounting for about $48 \%$ of the recorded amphipod fauna in the region. As has been noted in other studies (Winfield et al., 2006; Cardoso et al., 2011), such new records emphasise the importance of a taxonomic survey in these poorly studied habitats; the intertidal zone and shallow water of the Alacranes Reef's islands thus have great potential for the discovery of more new records and even new species, given that the present work only sampled on one of the Reef's islands.

Species inhabiting the intertidal zone and shallow water can be used as bioindicators inasmuch as the beaches are ecosystems that are affected by human action, for instance recreation (Defeo et al., 2009), which in the near future could become the major threat to the Alacranes Reef (Jordán-Dahlgren and Rodríguez-Martínez, 2003). Furthermore, given that coral reef islands are low-lying accumulations of unconsolidated carbonate sand and gravel deposited on coral reef platforms by the focussing effect of waves and currents (Stoddart and Steers, 1977), they are considered physically vulnerable to a range of climate change impacts including a rise in 
sea-level, changing weather and oceanographic wave regimes, and increased cyclone frequency and intensity (Webb and Kench, 2010). Therefore, as well as increasing the understanding of regional marine biodiversity, the amphipod species described in the current study may also serve as a baseline for shoreline monitoring by assessment of temporal change in faunal composition.

ACKnOWLedgements - This study was made possible through financial support from research project PAPIME-PE207210 and SEMARNATCONACyT108285, UNAM, Mexico. The field work was possible due to the help of Alfredo Gallardo and Fernando Mex (UNAM, Sisal), and the other members of the 2009 Alacranes Reef Biodiversity Expedition. A special thanks to the Oceanography Research Station in Progreso, Mexican Navy by the transportation logistics to Alacranes Reef. The authors thank the anonymous referees who helped to improve the manuscript.

\section{REFERENCES}

Appadoo, C. and Myers, A.A. 2003. Observations on the tube-building behaviour of the marine amphipod Cymadusa filosa Savigny (Crustacea: Ampithoidae). Journal of Natural History, 37(18): 2151-2164.

Arias-González, J.E.; González-Gándara, C.; Cabrera, J.L. and Christensen, V. 2012. Predicted impact of the invasive lionfish Pterois volitans on the food web of a Caribbean coral reef. Environmental Research, 111(7): 917-925.

Anker, A. 2010. A new genus and three new species of alpheid shrimps (Crustacea, Decapoda, Caridea) from the tropical American coasts. Zootaxa, 2652: 47-63.

Anker, A. 2012. Revision of the western Atlantic members of the Alpheus armillatus H. Milne Edwards, 1837 species complex (Decapoda, Alpheidae), with description of seven new species. Zootaxa, 3386: 1-109.

Anker, A. and De Grave, S. 2010. Holthuisaeus, a new genus for Periclimenes (Periclimenaeus) bermudensis Armstrong, 1940 (Decapoda, Palaemonidae, Pontoniinae). In: Fransen, C.H.J.M.; De Grave, S. and Ng, P.K.L. (Eds.), Studies on Malacostraca: Lipke Bijdeley Holthuis memorial volume. Brill, Leiden; Crustaceana Monographs, 14. 115-131.

Baldinger, A.J. 2000. Amphipoda of the Caribbean region and the Gulf of Mexico. Polskie Archiwum Hydrobiologii, 47(3-4): 697-702.

Barba, E. and Sánchez, A.J. 2005. Peracarid crustaceans of Central Laguna Madre Tamaulipas in the southwestern Gulf of Mexico. Gulf of Mexico Science, 23(2): 241-247.

Barnard, J.L. and Barnard, C.M. 1981. The amphipod genera Eobrolgus and Eyakia (Crustacea: Phoxocephalidae) in the Pacific Ocean. Proceedings of the Biological Society of Washington, 94(1): 295313.

Bousfield, E.L. 1970. Adaptive radiation in sandburrowing amphipod crustaceans. Chesapeake Science, 11(3): 143-154.
Bousfield, E.L. 1973. Shallow-water Gammaridean Amphipoda of New England. Ithaca, Cornell University Press, 312p.

Bousfield, E.L. 1984. Recent advances in the systematics and biogeography of landhoppers (Amphipoda: Talitridae) of the Indo-Pacific Region. Bishop Museum Special Publication, 72: 171-210.

Bynum, K.H. and Fox, R.S. 1977. New and noteworthy amphipod crustaceans from North Carolina, U.S.A. Chesapeake Science, 18(1): 1-33.

Cardoso, R.S.; Meireis, F. and Mattos, G. 2011. Crustaceans composition in sandy beaches of Sepetiba Bay, Rio de Janeiro, Brazil. Check List, 7(6): 778-781.

Charvat, D.L.; Nelson, W.G. and Allenbaugh, T.A. 1990. Composition and seasonality of sand-beach amphipod assemblages of the East Coast of Florida. Journal of Crustacean Biology, 10(3): 446-454.

Cházaro-Olvera, S.; Winfield, I.; Ortiz, M. and Álvarez, F. 2002. Peracarid crustaceans from three inlets in the southwestern Gulf of Mexico: new records and range extensions. Zootaxa, 123: 1-16.

Ciavatti, G. 1989. Les talitres (Crustacea: Amphipoda) des plages de la Guadaloupe. Description de deux espèces nouvelles. Annales del l'Institut océanographique, Paris, 65(2): 127-146.

Clarke, K.R. and Gorley, R.N. 2006. PRIMER v6: User Manual/Tutorial. Plymouth, PRIMER-E, 192p.

CONANP, 2006. Programa de conservación y manejo Parque Nacional Arrecife Alacranes. Mexico, Comisión Nacional de Áreas Naturales Protegidas, $170 \mathrm{p}$.

Connell, J.H. 1978. Diversity in tropical rain forest and coral reefs. Science, 199(4335): 1302-1310.

Cuevas-Jimenéz, A. and Euán-Ávila, J. 2009. Morphodynamics of carbonate beaches in the Yucatán Peninsula. Ciencias Marinas, 35(3): $307-$ 320.

Defeo, O.; McLachlan, A.; Schoeman, D.S.; Schlacher, T.A.; Dugan, J.; Jones, A.; Lastra, M. and Scapini, F. 2009. Threats to sandy beach ecosystems: A review. Estuarine, Coastal and Shelf Science, 81(1): 1-12.

Escobar-Briones, E. and Jiménez-Guadarrama, E.L. 2010. Macrocrustáceos (Peracarida, Decapoda) de fondos carbonatados del sector occidental del Banco de Campeche en el sur del Golfo de México. Revista Mexicana de Biodiversidad, 81: 63-72.

Escobar-Briones, E. and Winfield, I. 2003. Checklist of the benthic Gammaridean and Caprellidae (Crustacea: Peracarida: Amphipoda) from the Gulf of México Continental Shelf and Slope. Belgian Journal of Zoology, 133(1): 37-44.

Folk, R.L. 1967. Sand Cays of Alacrán Reef, Yucatán, Mexico: Morphology. The Journal of Geology, 75(4): 412-437.

Folk, R.L. and Robles, R. 1964. Carbonate sands of Isla Perez, Alacrán Reef complex, Yucatán. The Journal of Geology, 72(3): 255-292.

Gable, M.F.; Lazo-Wasem, E.A. and Baldinger, A.J. 2010. The Amphipoda of Bermuda-A century of taxonomy. Zoologica Beatica, 21: 131-141.

Jordán-Dahlgren E. and Rodríguez-Martínez, R.E. 2003. The Atlantic coral reefs of Mexico, p. 131158. In: J. Cortés (ed), Latin American coral reefs. Amsterdam, Elsevier Press.

Just, J. 1977. Amphyllodomus incurvaria gen. et sp. n. (Crustacea, Amphipoda), a remarkable leaf-cutting amphithoid from the marine shallows of Barbados. Zoologica Scripta, 6(3): 229-232. 
Karaman, G.S. and Barnard, J.L. 1979. Classificatory revision in Gammaridean Amphipoda (Crustacea), part 1. Proceedings of the Biological Society of Washington, 92(1): 106-165.

Knox, G.A. 2001. The ecology of seashores. Boca Raton, CRC Press, 557p.

Kornicker, L.S.; Bonet, F.; Cann, R. and Hoskin, C.M. 1959. Alacran Reef, Campeche Bank, Mexico. Publications of the Institute of Marine Science, 6: 1-22.

Krapp-Schickel, T. and Ruffo, S. 2001. A new Maeracoota from the Caribbean sea: Maeracoota galani n. sp. (Crustacea Amphipoda, Melitidae). Bollettino del Museo Civico di Storia Naturale di Verona, 25: 3-8.

Krapp-Schickel, T. and Vader, W. 2009. On some Maerid genera (Crustacea, Amphipoda, Maeridae) collected by the Hourglass Cruises (Florida). Part 1: Genera Anamaera, Ceradocus, Clessidra gen. nov., Jerbania, Maera, Meximaera, with a key to world Ceradocus. Journal of Natural History, 43(33-34): 2057-2086.

Lazo-Wasem, E.A.; Baldinger, A.J. and Gable, M.F. 1989. Pariphinotus Kunkel, 1910, the senior synonym of Heterophilas Shoemaker, 1933 (Crustacea: Amphipoda: Phliantidae). Postilla, 205: $1-5$.

Lazo-Wasem, E.A. and Gable, M.F. 1987. A review of recently discovered type specimens of Bermuda Amphipoda (Crustacea: Peracarida) described by B. W. Kunkel (1882-1969). Proceedings of the Biological Society of Washington, 100(2): 321-336.

LeCroy, S.E. 2000. An Illustrated Identification Guide to the Nearshore Marine and Estuarine Gammaridean Amphipoda of Florida, Volume 1, Families Gammaridae, Hadziidae, Isaeidae, Melitidae and Oedicerotidae. Tallahassee, Florida Department of Environmental Protection, 195p.

LeCroy, S.E. 2002. An Illustrated Identification Guide to the Nearshore Marine and Estuarine Gammaridean Amphipoda of Florida, Volume 2, Families Ampeliscidae, Amphilochidae, Amphithoidae, Aoridae, Argissidae and Haustoriidae. Tallahassee, Florida Department of Environmental Protection, $214 \mathrm{p}$.

LeCroy, S.E. 2004. An Illustrated Identification Guide to the Nearshore Marine and Estuarine Gammaridean Amphipoda of Florida, Volume 3, Families Bateidae, Biancolinidae, Cheluridae, Colomastigidae, Corophidae, Cyproideidae and Dexaminidae. Tallahassee, Florida Department of Environmental Protection, 91p.

LeCroy, S.E. 2007. An Illustrated Identification Guide to the Nearshore Marine and Estuarine Gammaridean Amphipoda of Florida, Volume 4, Families Anamixidae, Eusiridae, Hyalellidae, Hyalidae, Iphimediidae, Ischyroceridae, Lysianassidae, Megaluropidae and Melphidippidae. Tallahassee, Florida Department of Environmental Protection, $111 \mathrm{p}$.

LeCroy, S.E. 2011. An Illustrated Identification Guide to the Nearshore Marine and Estuarine Gammaridean Amphipoda of Florida, Volume 5, Families Leucothoidae, Liljeborgiidae, Neomegamphopidae, Ochlesidae, Phliantidae, Phoxocephalidae, Platyischnopidae, Pleustidae, Podoceridae, Pontoporeiidae, Sebidae, Stenothoidae, Synopiidae and Talitridae. Tallahassee, Florida Department of Environmental Protection, 209p.
LeCroy, S.E.; Gasca, R.; Winfield, I.; Ortiz, M. and Escobar-Briones, E. 2009. Amphipoda (Crustacea) of the Gulf of Mexico, p. 941-972. In: D.L. Felder and D.K. Camp (eds), Gulf of Mexico: Origins, Waters and Biota, Volume 1, Biodiversity. Texas, Texas A\&M University Press.

Ledoyer, M. 1986. Faune mobile des herbiers de phanerogames marines (Halodule et Thalassia) de la Laguna de Terminos (Mexique, Campeche). II. Les Gammariens (Crustacea). Anales del Instituto de Ciencias del Mar y Limnología, Universidad Nacional Autónoma de México, 13(3): 171-200.

Lewis, F.G. 1987. Crustacean epifauna of seagrass and macroalgae in Apalachee Bay, Florida, USA. Marine Biology, 94(2): 219-229.

Lewis, S.M. and Kensley, B. 1982. Notes on the ecology and behaviour of Pseudamphithoides incurvaria (Just) (Crustacea, Amphipoda, Ampithoidae). Journal of Natural History, 16(2): 267-274.

Liceaga-Correa, M.A. and Hernández-Núnez, H. 2000. Localización y dimensiones del arrecife Alacranes. Jaina, 11(2): 8-10.

Lowry, J.K. and Myers, A.A. 2009. Benthic Amphipoda (Crustacea: Peracarida) of the Great Barrier Reef. Zootaxa, 2260: 16.

Martín, A. and Díaz, Y.J. 2003. La fauna de anfípodos (Crustacea: Amphipoda) en las aguas costeras de la región oriental de Venezuela. Boletín del Instituto Español de Oceanografía, 19(1-4): 327-344.

McKinney, L.D. 1977. The origin and distribution of shallow water gammaridean Amphipoda in the Gulf of Mexico and Caribbean Sea with notes on their ecology. Texas A\&M University, Austin, USA, Ph.D. Thesis. 400pp. [Unpublished].

Mejía-Ortíz, L.M.; Yañez, G. and López-Mejía, M. 2006. Fauna of five anchialine caves in Cozumel Island, México. National Association for Cave Diving Journal, 39(1): 11-15.

Miloslavich, P.; Díaz, J.M.; Klein, E.; Alvarado, J.J.; Díaz, C.; Gobin, J.; Escobar-Briones, E.; Cruz-Motta, J.J.; Weil, E.; Cortés, J.; Bastidas, A.C.; Robertson, R.; Zapata, F.; Martín, A.; Castillo, J.; Kazandjian, A. \& Ortiz, M. 2010. Marine Biodiversity in the Caribbean: Regional Estimates and Distribution Patterns. PLoS ONE, 5(8): e11916. DOI 10.1371/ journal.pone.0011916

Moreno-Mendoza, R.; Gonzalez-Salas, C.; AguilarPerera, A.; Gallardo-Torres, A. and Nuno, S. 2011. First record of the white-eye goby, Bollmannia boqueronensis (Teleostei: Perciformes: Gobiidae) along the coast of the Yucatan Peninsula (Gulf of Mexico). Marine Biodiversity Records, 4(e25): 1-4.

Myers, A.A. 1977. Studies on the genus Lembos Bate. VI. Atlantic species: L. dentischium sp. nov., $L$. kunkelae sp. nov., $L$. rectangulatus sp. nov., $L$. unicornis Bynum \& Fox. Bollettino del Museo Civico di Storia Naturale di Verona, 4: 125-154.

Myers, A.A. 1979. Studies on the genus Lembos Bate. VIII. Atlantic species 5. L. triginus sp. nov., L. tempus sp. nov., L. spinicarpus (Pearse) comb. nov. with spp. inermis nov., L. ovalipes sp. nov., L. unifasciatus Myers ssp. reductus nov. Bollettino del Museo Civico di Storia Naturale di Verona, 6: 221-248. 
Myers, A.A. 1981. Amphipod Crustacea 1, Family Aoridae. Memoirs of the Hourglass Cruises, 5(5): 1-75.

Oliva-Rivera, J.J. 2003. The amphipod fauna of Banco Chinchorro, Quintana Roo, Mexico with ecological notes. Bulletin of Marine Science, 73(1): 77-89.

Ortiz, M. and Lalana, R. 1994. Two new species of the genus Elasmopus (Amphipoda: Gammaridea), from the Cuban marine waters. Travaux du Muséum National d'Histoire naturelle "Grigore Antipa", 34: 293-302.

Ortiz, M. and Lalana, R. 1996. Los anfípodos de la primera expedición conjunta Cuba-USA, a bordo del B/I Ulises, a las aguas del Archipélago SabanaCamagüey, Cuba, en 1994. Anales del Instituto de Biología, Universidad Nacional Autónoma de México, Serie Zoología, 67(1): 89-101.

Ortiz, M. and Lalana, R. 2010. Distribución de los anfípodos (Crustacea, Malacostraca, Peracarida) de los subórdenes Gammaridea, Caprellidea e Hyperiidea, presentes en el archipiélago cubano. Revista de Investigaciones Marinas, 31(2): 75-90.

Ortiz, M.; Martín, A. and Díaz, Y.J. 2007. Lista y referencias de los crustáceos anfípodos (Amphipoda: Gammaridea) del Atlántico occidental tropical. Revista de Biología Tropical, 55(2): 479-528.

Paz-Ríos, C.E.; Simóes, N. and Ardisson, P.L. 2013. Records and observations of amphipods (Amphipoda: Gammaridea and Corophiidea) from fouling assemblages in the Alacranes Reef, southern Gulf of Mexico. Marine Biodiversity Records, 6(e90): $1-16$.

Pearse, A.S. 1912. Notes on certain amphipods from the Gulf of Mexico, with description of new genera and new species. Proceedings of the United States National Museum, 43(1936): 369-379.

Plaisance, L.; Caley, M.J.; Brainard, R.E. and Knowlton, N. 2011. The diversity of coral reefs: What are we missing? PLoS ONE, 6(10): e25026.

Plaisance, L.; Knowlton, N.; Paulay, G. and Meyer, C. 2009. Reef-associated crustacean fauna: biodiversity estimates using semi-quantitative sampling and DNA barcoding. Coral Reefs, 28(4): 977-986.

Porri, F.; Hill, J.M. and McQuaid, C.D. 2011. Associations in ephemeral systems: the lack of trophic relationships between sandhoppers and beach wrack. Marine Ecology Progress Series, 426: 253-262.

Richards, V.P.; Stanhope, M.J. and Shivji, M.S. 2012. Island endemism, morphological stasis, and possible cryptic speciation in two coral reef, commensal Leucothoid amphipod species throughout Florida and the Caribbean. Biodiversity and Conservation, 21(2): 343-361.

Shoemaker, C.R. 1932. The amphipod Nototropis minikoi on the east coast of the United State. Proceedings of the Biological Society of Washington, 45(10): 199-200.

Shoemaker, C.R. 1933. Two new genera and six new species of Amphipoda from Tortugas. Papers from the Tortugas Laboratory, 28(15): 247-256.

Spalding, M.D.; Ravilious, C. and Green, E.P. 2001. World atlas of coral reefs. Berkeley, University of California Press, 424p.

Stoddart, D.R. and Steers, J.A. 1977. The nature and origin of coral reef islands, p. 59-105. In: O.A. Jones and R. Endean (eds), Biology and geology of coral reefs, Volume IV, Geology 2. New York, Academic Press.
terHorst, C.P. 2012. Context-dependent orientation cues in a supratidal amphipod. Marine and Freshwater Behaviour and Physiology, 45(1): 45-50.

Thomas, J.D. 1993. Identification manual for the marine Amphipoda: (Gammaridea). I. Common coral reef and rock bottom amphipods of South Florida. Tallahassee, Florida Department of Environmental Protection, 83p.

Thomas, J.D. and Barnard, J.L. 1985. Two new species of two new gammaridan genera (Crustacea: Amphipoda) from the Florida Keys. Proceedings of the Biological Society of Washington, 98(1): 191-203.

Thomas, J.D. and Klebba, K.N. 2007. New species and host associations of commensal leucothoid amphipods from coral reefs in Florida and Belize (Crustacea, Amphipoda). Zootaxa, 1494: 1-44.

Thomas, J.D. and Ortíz, M. 1995. Leucothoe laurensi, a new species of leucothoid amphipod from Cuban waters (Crustacea, Amphipoda, Leucothoidae). Proceedings of the Biological Society of Washington, 108(4): 613-616.

Trujillo-Pisanty, D.; Chávez-Solís, E.M.; Solís-Weiss, V and Hermoso-Salazár, M. 2010. Peracarids (Crustacea: Malacostraca) from cenote Aerolito, Cozumel, Mexican Caribbean. Cahiers de Biologie Marine, 51(2): 177-180.

Varela, C.; Ortiz, M and Lalana, R. 2003. Crustáceos (Peracarida y Decapoda) de la costa sur de Guanahacabibes, Cuba. Revista de Investigaciones Marinas, 24(1): 73-76.

Webb, A.P. and Kench, P.S. 2010. The dynamic response of reef islands to sea-level rise: Evidence from multi-decadal analysis of island change in the Central Pacific. Global and Planetary Change, 72(3): 234-246.

White, K.N. 2011a. A taxonomic review of the Leucothoidae (Crustacea: Amphipoda). Zootaxa, 3078: 1-113.

White, K.N. 2011b. Caribbean Leucothoidae (Crustacea: Amphipoda) of Panama. Gulf and Caribbean Research, 23: 23-35.

Wilkinson, T.; Wiken, E.; Bezaury-Creel, J.; Hourigan, T.; Agardy, T.; Herrmann, H.; Janishevski, L.; Madden, C.; Morgan, L. and Padilla, M. 2009. Marine Ecoregions of North America. Montreal, Commission for Environmental Cooperation, 200p.

Winfield, I.; Cházaro-Olvera, S.; Ortiz, M. and PalomoAguayo, U. 2011. Lista actualizada de las especies de anfípodos (Peracarida: Gammaridea y Corophiidea) marinos invasores en México. Revista de Biología Marina y Oceanografía, 46(3): 349-361.

Winfield, I. and Escobar-Briones, E. 2007. Anfípodos (Crustacea: Gammaridea) del sector norte del Mar de Caribe: listado faunístico, registros nuevos y distribución espacial. Revista Mexicana de Biodiversidad, 78(1): 51-61.

Winfield, I.; Escobar-Briones, E. and Morrone, J.J. 2006. Update checklist and identification of areas of endemism of benthic amphipods (Caprellidae and Gammaridea) from offshore habitats in the SW GoM. Scientia Marina, 70(1): 99-108. 
Winfield, I. and Ortiz, M. 2011. Crustáceos con bolsa incubadora (Crustacea: Malacostraca: Peracarida), p. 277-286. In: V. Hernández-Ortiz (ed), La biodiversidad en Veracruz: Estudio de Estado. Volumen II, Capítulo Invertebrados. Ciudad de México, Comisión Nacional para el Conocimiento y Uso de la Biodiversidad, Instituto de Ecología.

Zimmerman, R.; Gibson, R. and Harrington, J. 1979.

Herbivory and detritivory among gammaridean amphipods from a Florida seagrass community. Marine Biology, 54(1): 41-47. 